\title{
SALMONELLA SPP. IN RAW BROILER PARTS: OCCURRENCE, ANTIMICROBIAL RESISTANCE PROFILE AND PHAGE TYPING OF THE SALMONELLA ENTERITIDIS ISOLATES
}

\author{
Aldemir Reginato Ribeiro" ${ }^{1 *}$; Aline Kellermann¹; Luciana Ruschel dos Santos²; Marjo Cadó Bessa ${ }^{3}$; \\ Vladimir Pinheiro do Nascimento ${ }^{1}$
}

\begin{abstract}
${ }^{1}$ Centro de Diagnóstico e Pesquisa em Patologia Aviária, Faculdade de Veterinária, Universidade Federal do Rio Grande do Sul, Porto Alegre, RS, Brasil; ${ }^{2}$ Faculdade de Agronomia e Medicina Veterinária, Universidade de Passo Fundo, Passo Fundo, RS, Brasil; ${ }^{3}$ Departamento de Medicina Veterinária Preventiva, Faculdade de Veterinária, Universidade Federal do Rio Grande do Sul, Porto Alegre, RS, Brasil
\end{abstract}

Submitted: April 03, 2006; Returned to authors for corrections: June 01, 6 Approved: April 09, 2007.

\begin{abstract}
The present study was carried out to evaluate the occurrence of Salmonellae in raw broiler parts and to determine the antimicrobial resistance profile of the isolated strains. Twenty-four (39.3\%) broiler parts samples were positive for Salmonella and twenty-five Salmonella strains were isolated, since two different serovars were detected in one single positive sample. Salmonella Enteritidis was the most prevalent serovar. Among Salmonella Enteritidis isolates, 95.2\% belonged to Phage Type 4 (PT4) (20/21) and 4.8\% to PT7 (1/21). Twenty-two (88\%) strains of Salmonella were resistant to at least one antimicrobial agent, generating eight different resistance patterns. The $S$. Typhimurium (n: 1) and $S$. Hadar (n: 3) isolates presented multiple resistance. Three $S$. Enteritidis isolates were susceptible to all antimicrobials tested, two were resistant only to tetracycline. The high prevalence of Salmonella in the broiler parts strenghtens the importance of the use of good manufacturing practices (GMP), and HACCP. The results also emphasize the need for the responsible use of antimicrobials in animal production.
\end{abstract}

Key words: Salmonella, broiler parts, antimicrobial resistance, phage typing

\section{INTRODUCTION}

Food from animal origin are important elements within the human food supply chain, but sometimes they can be a source of food-borne pathogens, such as Salmonella, especially in the case of poultry products, which are recognized as frequent vehicles of transmission of that microrganism (29).

Salmonella, once introduced by live chickens or other means into the processing plant, will progress along the processing line (19), jeopardizing the product's final microbiological quality for human consumption. The occurrence of Salmonella in broiler chicken cuts, in studies undertaken in different countries, can vary for instance from $1.5 \%$ in Northern Ireland (26) to $51.1 \%$ in Belgium(31).

Antimicrobials have been used in poultry as growth promoters, and for prophylatic or therapeutic purposes.
However, their indiscriminate use is causing increasing resistance amongst Salmonella strains and other bacteria (4), which may be present in foods, and thus transmitted to humans through the food chain (1).

The present study was carried out to evaluate the occurrence of Salmonella in broiler chicken parts, to estimate the resistance profiles of the isolates and to determine the phage type the Salmonella Enteritidis isolates.

\section{MATERIALS AND METHODS}

\section{Collection of Samples}

The study was carried out using 61 broiler chicken parts (wings, whole legs, boneless breasts and backs) collected in the period from September, 30 to December, 20, 1996, in a processing plant located in Southern Brazil.

*Corresponding Author. Mailing address: Av. Bento Gonçalves, 9090, Agronomia - cep: 91540-000, Porto Alegre, RS, Brasil. Tel.: (51) 3308-6939.

E-mail: aldemir_r@yahoo.com 


\section{Isolation and Identification Procedure}

Salmonellae were isolated using the microbiological method recommended by the Brazilian Agriculture Ministry (5). Briefly, $25 \mathrm{~g}$ of skin and muscle, collected from each broiler chicken part under aseptic conditions, were homogenized with $225 \mathrm{~mL}$ of $1 \%$ Buffered Peptone Water (BPW) (Merck AG, Darmstadt, Germany), and incubated $36 \pm 1.0^{\circ} \mathrm{C}$ for $16-20 \mathrm{~h}$ (pre-enrichment step). One $\mathrm{mL}$ of the pre-enrichment broth was transfered into 9 $\mathrm{mL}$ of Tetrathionate broth (Merck), and $0.1 \mathrm{~mL}$ into $9.9 \mathrm{~mL}$ of Rappaport-Vassiliadis broth (Merck), and incubated at $36 \pm 1.0^{\circ} \mathrm{C}$, and $41 \pm 0.5^{\circ} \mathrm{C}$ respectively (selective enrichment step). After $24 \mathrm{~h}$, the selective enrichment cultures were streaked onto XLT4 (Difco, Detroid, MI, USA) and Rambach $®$ (Merck) agar plates and incubated for $18-24 \mathrm{~h}$ at $36 \pm 1.0^{\circ} \mathrm{C}$. Typical colonies were identified by biochemical and serological tests.

Complete antigenic characterization and serovar identification was performed by the Enteric Pathogens Laboratory from the Oswaldo Cruz Institute Foundation, Rio de Janeiro (FIOCruz-RJ).

\section{Antimicrobial Resistance Test}

The antimicrobial resistance test was performed using the disk diffusion method on Mueller-Hinton Agar, according to the Clinical and Laboratory Standards Institute (CLSI, formerly NCCLS) (18). The antimicrobials were ampicillin $10 \mu \mathrm{g}$, cyprofloxacin $5 \mu \mathrm{g}$, chloramphenicol $30 \mu \mathrm{g}$, enrofloxacin $5 \mu \mathrm{g}$, gentamycin $10 \mu \mathrm{g}$, kanamycin $30 \mu \mathrm{g}$, nalidixic acid $30 \mu \mathrm{g}$, nitrofurantoin $300 \mu \mathrm{g}$, norfloxacin $10 \mu \mathrm{g}$, polymixin B $300 \mathrm{I} . \mathrm{U}$. , streptomycin $10 \mu \mathrm{g}$, and tetracycline $30 \mu \mathrm{g}$. Escherichia coli ATCC 25922 was used as a reference strain. An isolate was classified as multiple resistant when demonstrated resistance to two or more agents (10).

\section{Phage Typing}

Twenty one Salmonella Enteritidis isolates were phage typed at the FIOCruz-RJ. The phage types were determined according to Ward et al. (32). Samples were inoculated in tubes with 1.5 $\mathrm{mL}$ of phage broth and then incubated, with agitation at $37^{\circ} \mathrm{C}$ for an average of two hours. Samples showing turbidity equivalent to the 0.5 level of the MacFarland scale were checked in a photocolorimeter. The selected phage broths were poured on phage agar plates, homogenized, and the excess of fluid was removed with a sterile pipette. The plates were left drying up for 20 minutes. Finally, $10 \mathrm{~mL}$ from each one of the 10 selected phage solutions were poured onto plates previously divided in ten quadrants, and incubated at $37^{\circ} \mathrm{C}$ for 24 hours.

\section{RESULTS AND DISCUSSION}

Twenty four out of the 61 raw broiler parts samples (39.3\%) were positive for Salmonella, which is in line with other papers on the incidence of Salmonella in frozen and refrigerated poultry cuts that reported $41.8 \%$ (30) and 51.1\% (31) in Belgium, $42.4 \%$ in the United States (7), but differ from the $1.5 \%$ found in Northern Ireland (26). Surveys performed in Brazil, using broiler chicken cuts, indicated the presence of Salmonella in 22.8\% (11) and 35\% of the samples (12) in São Paulo and $14.2 \%$ in Rio de Janeiro (23).

Factors such as the samples origin, the year in which the studies were undertaken, the number of samples and their condition (frozen or refrigerated), the sampling procedure, the flock level of contamination, the quality of sanitation applied in the processing plants, possible cross contamination between the products, and the testing methodology $(6,31)$. must be taken into consideration when comparing the results obtained in the present study.

Salmonella Enteritidis was the most frequent serovar, representing 21 (84\%) of the 25 Salmonellae identified from the 24 positive samples. The other isolates were three Salmonella Hadar (12\%) and one Salmonella Typhimurim (4\%). In one positive sample, two serovars were detected, $S$. Enteritidis and $S$. Hadar.

The number of $S$. Enteritidis isolated in this work confirms the existing preoccupation regarding this serovar being frequently involved in food poisoning outbreaks in humans. This was true in Italy, where the evidence of $S$. Enteritidis infection in humans increased from $2.4 \%$ to $57.1 \%$ between 1982 and 1992 , and from $0.5 \%$ to $22.8 \%$ in foodstuffs (14). Similarly, 150 outbreaks of food poisoning caused by Salmonella Enteritidis were recorded in Argentina between 1986 and 1993 (8).

In Brazil, $S$. Enteritidis has been the most prevalent serovar detected in human infections (27), in chicken carcasses (24), in foodstuffs, in the environment, water, sewage, chiller water, animal feed, animal viscera and faeces (28) and also in poultry flocks (15).

The phage typing of $S$. Enteritidis isolates showed that 95.2\% (20/21) belonged to phage type 4 (PT4) and 4.8\% (1/21) to PT7. Phage type 4 has been shown to be the most common phage type in several countries.

Santos et al. (25) showed that $93.3 \%$ of $S$. Enteritidis isolated from broiler carcasses in the State of Rio Grande do Sul, Brazil, belonged to the PT4. In Spain, Domínguez et al. (13) found PT4 isolates in $58.8 \%$ of retail, chicken meat samples analysed, while Liebana et al. (16) showed that PT4 was the most common phage type in English poultry farms.

Regarding the antimicrobial resistance, the present results (Table 1) indicated that $88 \%$ of Salmonella isolates $(22 / 25)$ were resistant to one or more antimicrobial agent, presenting eight different patterns of resistance (Table 2). Multiple resistance was not observed in five of the $21 \mathrm{~S}$. Enteritidis isolates, while 3 were susceptible to all antimicrobials tested and 2 were resistant only to tetracycline. Multiple resistance was also found in the $S$. Typhimurium, and in all three $S$. Hadar isolates. 
Table 1. Antimicrobial resistance in Salmonella strains isolated from raw broiler parts.

\begin{tabular}{lccccccccccccc}
\hline \multirow{2}{*}{ Serovars } & \multirow{2}{*}{$\begin{array}{c}\text { Number of } \\
\text { strains tested }\end{array}$} & \multicolumn{10}{c}{ Number of resistant strains $(\%)$} \\
\cline { 3 - 13 } & AMP & CIP & CHL & ENR & GEN & KAN & NAL & NIT & NOR & PB & STR & TET \\
\hline S. Enteritidis & 21 & 0 & 0 & 0 & $2(9.5)$ & 0 & 0 & $14(66.6)$ & $8(38.1)$ & 0 & 0 & 0 & $17(80.9)$ \\
$S$. Hadar & 3 & 0 & 0 & 0 & 0 & 0 & 0 & 0 & 0 & 0 & 0 & $3(100)$ & $3(100)$ \\
S. Typhimurium & 1 & 0 & 0 & 0 & 0 & 0 & 0 & $1(100)$ & 0 & 0 & 0 & 0 & $1(100)$ \\
\hline Total & 25 & 0 & 0 & 0 & $2(8.0)$ & 0 & 0 & $15(60.0)$ & $8(32.0)$ & 0 & 0 & $3(12.0)$ & $21(84.0)$ \\
\hline
\end{tabular}

AMP: ampicillin; CIP: ciprofloxacin; CHL: chloramphenicol; ENR: enrofloxacin; GEN: gentamicin; KAN: kanamycin; NAL: nalidixic acid; NIT: nitrofurantoin; NOR: norfloxacin; PB: polimyxin B; STR: streptomycin; TET: tetracycline.

Table2. Distribution of antimicrobial resistance patterns in Salmonella strains.

\begin{tabular}{lcccc}
\hline Patterns & $S$. Enteritidis & $S$. Hadar & $S$. Typhimurium & Total \\
\hline Susceptible & 3 & - & - & 3 \\
TET & 2 & - & - & 2 \\
NAL, TET & 6 & - & 1 & 7 \\
STR, TET & - & 3 & - & 3 \\
NIT, TET & 2 & - & - & 2 \\
NAL, NIT & 1 & - & - & 1 \\
ENR, NAL, TET & 2 & - & - & 2 \\
NAL, NIT, TET & 5 & - & - & 5 \\
\hline
\end{tabular}

AMP: ampicillin; CIP: ciprofloxacin; CHL: chloramphenicol; ENR: enrofloxacin; GEN: gentamicin; KAN: kanamycin; NAL: nalidixic acid; NIT: nitrofurantoin; NOR: norfloxacin; PB: polimyxin B; STR: streptomycin; TET: tetracycline.

Resistance to tetracycline was observed in $84 \%$ of the isolates, which is higher than that the $46.6 \%$ found in Dakar, Senegal (3), the $36 \%$ in Porto, Portugal (2) and also the $6.2 \%$ in Brazil (24). This elevated resistance may be explained by the possible difusion of the tet $(\mathrm{A})$ resistance gene, which was observed in Italy by Pezzella et al. (20) in an epidemiological study with Salmonella strains isolated from animals.

Resistance to nitrofurantoin (32\%), and streptomycin (16\%) was low when compared to the $95 \%$ found by Cardoso et al. (9) in S. Enteritidis, and the $100 \%$ found by Ribeiro et al. (22) in S. Hadar.

The Salmonellae presented resistance to nalidixic acid (60\%) and enrofloxacin (8\%). Other authors like Molbak et al. (17) have also observed an increase in quinolone resistance to Salmonella, wich is a cause for concern, since this resistance is mediated by chromosomes (21). On the other hand, we have not found resistance to norfloxacin and ciprofloxacin, which is in accordance to Cardoso et al. (9).
The high frequency of Salmonella (39.3\%) in broiler parts detected in the present study can be explained by the more extensive handling of the birds during the processing, fact that reinforces the paramount importance of implementing good manufacturing practices (GMP), and Hazard Analysis and Critical Control Points (HACCP) systems. The levels of antimicrobial resistance presented here highlight the need for responsible use of antimicrobial agents in food animals, and indicates the need for continuous surveillance.

\section{ACKNOWLEDGEMENTS}

The authors wish to acknowledge CDPA-UFRGS' staff for their technical assistance, and the National Council for Scientific and Technological Development (CNPq) for the financial support.

\section{RESUMO}

\section{Salmonella spp. em cortes de frango: ocorrência, resistência antimicrobiana e fagotipificação dos isolados de Salmonella Enteritidis}

Este trabalho foi conduzido para avaliar a ocorrência de Salmonella em cortes de frango e para determinar o perfil de resistência antimicrobiana das cepas isoladas. Vinte e quatro $(39,3 \%)$ cortes de frango foram positivas para Salmonella, tendo sido isoladas vinte e cinco cepas de Salmonella, uma vez que em uma amostra isolaram-se dois sorovares. Salmonella Enteritidis foi o sorovar prevalente. Entre as Salmonella Enteritidis isoladas, 95,2\% pertencem ao Fagotipo 4 (PT4) (20/ 21) e $4,8 \%$ ao PT7 (1/21). Vinte e duas (88\%) cepas de Salmonella foram resistentes a pelo menos um agente antimicrobiano e oito diferentes padrões de resistência foram observados. $S$. Typhimurium (n:1) e $S$. Hadar (n: 3), apresentaram múltipla resistência. Três cepas de $S$. Enteritidis foram sensíveis a todos os antimicrobianos e duas resistentes somente a tetraciclina. A 
elevada ocorrência de Salmonella nos cortes de frango utilizados no presente estudo reforça a importância das normas de boas práticas de fabricação, bem como dos controles de perigos e pontos críticos de controle. No tocante aos níveis de resistência a antimicrobianos, os resultados enfatizam a necessidade do uso responsável dos mesmos na produção animal.

Palavras chaves: Salmonella, partes de frango, resistência antimicrobiana, fagotipagem.

\section{REFERENCES}

1. Aarestrup, F.M. (1999). Association between the consumption of antimicrobial agents in animal husbandry and the occurrence of resistant bacteria among food animals. Int. J. Antimicrob. Agents, $12,279-285$.

2. Antunes, P.; Réu, C.; Souza, J.C.; Peixe, L.; Pestana, N. (2003). Incidence of Salmonella from poultry products and their susceptibility to antimicrobial agents. Int. J. Food Microbiol., 82, 97-103.

3. Bada-Alambedji, R.; Fofana, A.; Sedi, M.; Akakpo, A.J. (2006). Antimicrobial Resistance of Salmonella Isolated from Poultry Carcasses in Dakar (Senegal). Braz. J. Microbiol., 37, 510-515.

4. Berchieri Jr., A.; Adachi, S.Y.; Calzada, C.T.; Paulillo, A.C.; SchokenIturrino, R.P.; Tavechio, A.T. (1989). Farinha de Carne como Fonte de Salmonella em Granja Avícola. Pes. Vet. Bras., 9(1/2), 9-12, 1989.

5. Brasil. Ministério da Agricultura, Pecuária e Abastecimento / Secretaria de Defesa Agropecuária. Método Analítico de Carcaças de Aves e Pesquisa de Salmonella. Diário Oficial da União. Brasília, Portaria no 8, de 23 de janeiro de 1995. p.1182-1184. 27 de janeiro de 1995. Seção I.

6. Bryan, F.L.; Doyle, M.P. (1995). Health risk and consequences of Salmonella and Campylobacter jejuni in raw poultry. J. Food Prot., 58, 326-344.

7. Bokanyi Jr., R.P.; Stephens, J.F.; Foster, D.N. (1990). Isolation and Characterization of Salmonella from Broiler Carcasses or Parts. Poult. Sci., 69: 592-598.

8. Caffer, M.I.; Eiguer, T. (1994). Samonella enteritidis in Argentina. Int. J. Food Microbiol., 21, 15-19.

9. Cardoso, M.O.; Ribeiro, A.R.; Santos, L.R.; Pilotto, F.; Moraes, H.L.S.; Salle, C.T.P.; Rocha, S.L.S.; Nascimento, V.P. (2006). Antibiotic resistance in Salmonella Enteritidis isolated from broiler carcasses. Braz. J. Microbiol., 37, 368-371.

10. Carramiñana, J.J.; Rota, C.; Agústin, I.; Herrera, A. (2004). High prevalence of multiple resistance to antibiotics in Salmonella serovars isolated from a poultry slaugterhouse in Spain. Vet. Microbiol., 104, 133-139.

11. Carvalho, A.C.F.B.; Cortez, A.L.L. (2005). Salmonella spp. em carcaças, carne mecanicamente separada, lingüiças e cortes comerciais de frango. Ciênc. Rural, 35, 1465-1648.

12. Costa, F.N.; Rossi Júnior, O.D.; Nader Filho, A.; Tavechio, A.T. (1997). Sorovares de Salmonella isoladas de carcaças e cortes de frango obtidos na indústria e no comércio em Jaboticabal, Estado de São Paulo, em 1996. Rev. Bras. Ciên. Vet., 4, 97-100.

13. Domínguez, C.; Gómez, I.; Zumalacárregui, J. (2002). Prevalence of Salmonella and Campylobacter in retail chicken meat in Spain. Int. J. Food Microbiol., 72, 165-168.

14. Fantasia, M.; Filetici, E. (1994). Salmonella enteritidis in Italy. Int. J. Food Microbiol., 21, 7-13.

15. Kanashiro, A.M.; Stoppa, G.F.Z.; Cardoso, A.L.S.P.; Tessari, E.N.C.; Castro, A.G.M. (2005). Serovars of Salmonella spp Isolated from
Broiler Chickens and Commercial Breeders in Diverse Regions in Brazil July 1997 to December 2004. Braz. J. Poult. Sci., 7, 195-198.

16. Liebana, E.; Garcia-Migura, L.; Breslin, M.F.; Davies, R.H.; Woodward, M.J. (2001). Diversity os Strains of Salmonella enterica serotype Enteritidis from English Poultry Farms Assessed by Multiple Genetic Fingerprinting. J. Clin. Microbiol., 39(1), 154-161.

17. Molbak, K.; Gerner-Smidt, P.; Wegerner, H.C. (2002). Increasing Quinolone Resistance in Salmonella enterica serotype Enteritidis. Emerging Infect. Dis., 8, 514-515.

18. Clinical and Laboratory Standards Institute (CLSI, formerly NCCLS - National Committee for Clinical Laboratory Standards). (2003). Performance Standards for Antimicrobial Disk Susceptibility Tests; Approved Standard - Eighth Edition. NCCLS Document M2-A8. Wayne, Pennsylvania, USA.

19. Olsen. J.E.; Brown, D.J.; Madsen, M.; Bisgaard, M. (2003). Crosscontamination with Salmonella on a broiler slaughterhouse line demonstrated by the use of epidemiological markers. J. Appl. Microbiol., 94: 826-835.

20. Pezzella, C.; Ricci, A.; DiGiannatale, E.; Luzzi, I.; Carattoli, A. (2004). Tetracycline and Streptomycin Resistance Genes, Transposons, and Plasmids in Salmonella enterica Isolated from Animals in Italy. Antimicrob. Agents Chemother., 48(3), 903-908.

21. Piddock, L.J.V. (2002). Fluoroquinolone resistance in Salmonella serovars isolated from human and food animals. FEMS Microbiol. Rev., 26, 3-16.

22. Ribeiro, A.R.; Kellermann, A.; Santos, L.R.; Fittél, A.P.; Nascimento, V.P. (2006). Resistência Amtimicrobiana em Salmonella enterica subsp. enterica Sorovar Hadar Isoladas de Carcaças de Frango. Arq. Inst. Biol., 73(3), 357-360.

23. Sá Barreto, E.S.; Ramos, S.M. (1999). Pesquisa de Salmonella em cortes congelados de frango comercializados no Município do Rio de Janeiro. Hig. Aliment., 13, 53-54.

24. Santos. S.M.S.; Berchieri Jr. A.; Fernandes, S.A.; Tavechio, A.T.; Amaral, L.A. (2000). Salmonella em carcaças de frango congeladas. Pes. Vet. Bras., 20, 39-42.

25. Santos, L.R.; Nascimento, V.P.; Oliveira, S.D.; Rodrigues, D.P.; Reis, E.M.F.; Seki, L.M.; Ribeiro, A.R.; Fernandes, S. (2003). Phage Types of Salmonella Enteritidis Isolated from Clinical and Food Samples, and from Broiler Carcasses in Southern Brazil. Rev. Inst. Med. Trop. S. Paulo, 45(1), 1-4.

26. Soultos, N.; Koidis, P.; Madden, R.H. (2003). Presence of Listeria and Salmonella spp. In retail chicken in Northern Ireland. Letters Appl. Microbiol., 37, 421-423.

27. Tavechio, A.T.; Fernandes, S.A.; Neves, B.C.; Dias, A.M.G.; Irino, K. (1996). Changing patterns of Salmonella serovars: increase of Salmonella Enteritidis in São Paulo, Brazil. Rev. Inst. Trop. S. Paulo, 38(5), 315-322.

28. Tavechio, A.T.; Ghilardi, A.C.R.; Peresi, J.T.M.; Fuzihara, T.O.; Yonamine, E.K; Jakabi, M.; Fernandez, S.A. (2002). Salmonella serotypes Isolated from Nonhuman Sources in São Paulo Brazil, from 1996 through 2000. J. Food Prot., 65(6), 1041-1044.

29. Todd, E.C.D. (1980). Poultry-associated Foodborne Disease - Its Occurrence, Cost, Sources and Prevention. J. Food Prot., 43(2), 129-139.

30. Uyttendaele, M.R.; Debevere, J.M.; Lips, R.M.; Neyts, K.D. (1998). Prevalence of Salmonella in poultry carcasses and their products in Belgium. Int. J. Food Microbiol., 40, 1-8.

31. Uyttendaele, M.; De Troy, P.; Debevere, J. (1999). Incidence of Salmonella, Campylobacter jejuni, Campylobacter coli, and Listeria monocytogenes in Poultry Carcasses and Different Types of Poultry Products for Sale on the Belgian Retail Market. J. Food Prot., 62(7), 735-740.

32. Ward, L.R.; de Sa, J.D.H. ; Rowe, B. (1987). A phage typing scheme for Salmonella enteritidis. Epidem. Infect., 99, 291-294. 